\title{
SHARED OPEN SPACES IN GATED DEVELOPMENTS ISSUES OF SUSTAINABILITY AWARENESS AND SATISFACTION
}

\author{
Faisal Abdul Maksoud*, Seamus Filor** and Ghada Yassein* \\ *Department of Architecture, Minoufiya University, Egypt \\ ** Department of Landscape Architecture, University of Edinburgh, Scotland, UK.
}

\begin{abstract}
In gated residential developments, it was believed that the waning provision of well-landscaped open spaces including man-made lakes, swimming pools and golf courses, have all added to Egypt's water woes consuming an overwhelming amount of much needed water, a valuable resource highly appreciated in arid zones. Also, lack of peoples' understanding of ecology remains major obstacles to achieving more sustainable residential landscapes.
\end{abstract}

The purpose of this paper is twofold: firstly, using a hypothetical framework, the present study provides insights about sustainability awareness and residents' satisfaction in gated residential developments. Secondly, it aims at presenting new evidences; through descriptive and inferential analyses of a Resident Satisfaction Survey, a key principle relating to satisfaction in residential developments has been identified. That is: the need to encourage residents' participation in management process to ensure maximizing their satisfaction.

Here, the study attempted to understand the relationship between residential landscape management and satisfaction, which is a perceptual construct of residents, then using residents' participation in landscape management in order to enhance the understanding of sustainability concepts and the implementation of sustainability measures. It will conclude with a brief summary of some of the main points highlighted and provide insight for planning and managing of residential landscapes to improve both landscape sustainability and residents' satisfaction.

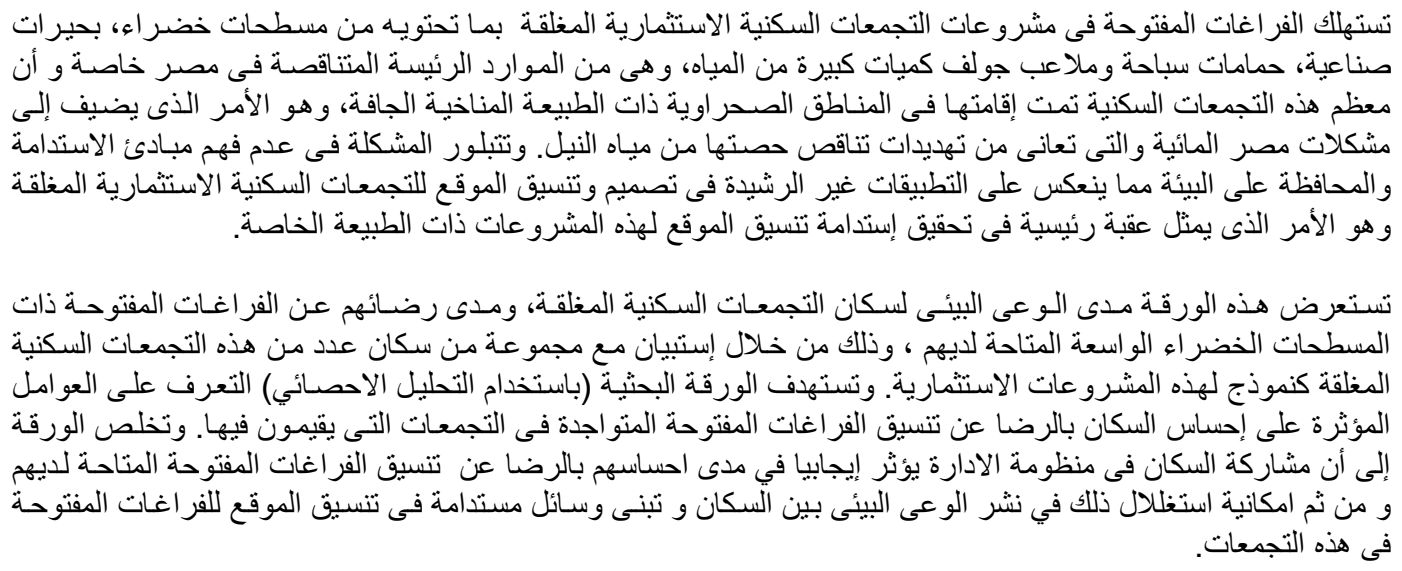

Keywords: Gated residential developments (GRDs) - Residential landscape - Satisfaction Sustainable Landscape - Water-efficient landscaping 


\section{INTRODUCTION}

The 'natural' and 'urban' landscapes can influence the way we behave and feel. The reasons of our respond to an environment are partly based on the information immediately available and partly based on the past experience of the individual observer. Some theorists argue that there are evolutionary reasons for such reactions. Research in environmental psychology has explored people's preferences for landscapes in order to identify the variables that make up the landscapes that people prefer.

Considerably, the scope of landscape architecture varies from broad projects such as town planning and large national parks to narrow projects such as small parks, urban plazas, commercial centers, and residences [1]. Generally, landscape architecture can be defined as "the part of environment ${ }^{1}$ that we can engage with at a given time" [2-66].

In that sense, every specific study needs to define the concept of landscape depending on the research objectives. For the purpose of this research, shared open spaces stand for the common landscape areas in the gated residential developments commonly known as compounds and located on the fringe of the Greater Cairo Region in new desert towns and main regional roads such as: (Cairo /Alexandria and Cairo/Ismailia desert roads) (figure 1). These shared residential landscapes with significant amounts of vegetation are frequently jointly owned by the residents and maintained in a type of management structure.

\section{THEORETICAL BACKGROUND}

\subsection{Satisfaction and residential landscape}

Satisfaction is the complex perceptual construct of a person based on his/her objective, subjective environments and personal characteristics [3]. In the residential context, residents experience a strong community attachment when they find their homes and community satisfactory [4]. It is also believed that as a part of the environment, perceived landscapes within residential areas affect residents' satisfaction. For instance, the presence of various forms of landscape elements within a neighborhood is positively related to higher levels of satisfaction $[5,6,7]$. To contribute so significantly to residential satisfaction, (Kaplan, Kaplan, \& Ryan, 1998) [8] suggest ways to enhance micro-restorative opportunities. Among these are: providing visual access, smooth ground textures, trees, and the sense of enclosure.

\subsection{Landscape sustainability}

According to (Pease) [9], it seems that the word 'sustainability' is appearing everywhere. Echoing Pease, (Lyndon) [10] and (Young) [11] write that it has become a 'catch word of the times' and certainly the landscape literature would lead one to this conclusion.

Generally, the most widely accepted definition seems to be the one coined by (World Commission on Environment and Development): sustainable development meets the needs of the present without compromising the needs of future generations to meet their own needs [12]. The APLD (Association of Professional Landscape Designers) paraphrase that as "living today without borrowing from tomorrow"'[13].

Sustainability forces theorist, designer, or critic to address a number of fundamental questions such as what is nature and human relationship to it? Is it of necessity linked to the landscape it occupies or is that connection merely conditional? How does one develop a sustainable landscape design that takes into account the local, traditional, social organisation? Are the costs and benefits of sustainability to be distributed within a society? At what temporal and spatial scale is a given landscape design considered sustainable? How does a sustainable design take into account dynamic technologies, ecologies, and social orders? Finally, (Young) [11] argues that sustainability will never be achieved without first providing answers for the issue of how does a designer inform his practice with theory and how do theorists gain the insights of practice?

\subsection{Dimensions of sustainable landscape}

Sustainable development is commonly considered to be at the intersection of environment, economy, and society, even if these terms are now expanded to include ecosystem services and limits, fair and durable prosperity, health and social justice. Meanwhile, many authors point out a fourth dimension of 'political sustainability', referring to governance mechanisms delivering sustainable development using responsible science and economics. It is also of particular importance to consider what might be described as 'aesthetic sustainability', for the reason that much of landscape's importance has been its visual appeal, together with intuitive associations between visual harmony, ecological integrity, human well being, and place identity [14].

\footnotetext{
${ }^{1}$ Environment is everything surrounding us these include natural and man-made elements, physical and biological resources and ourselves as well.
} 


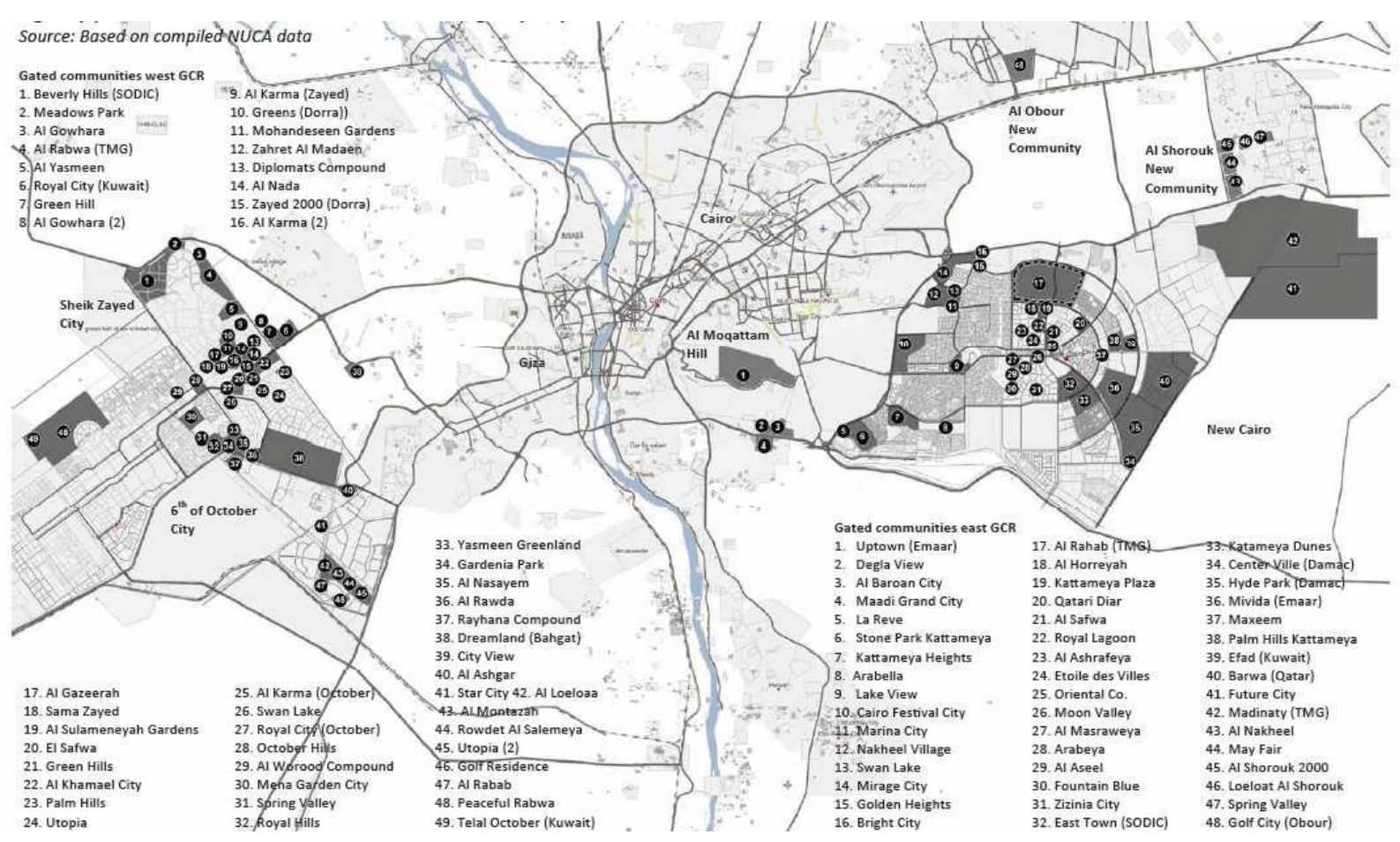

Fig 1. Gated Communities Flourishing in New Desert Towns. Source: (Ghonimi, Elzamly, Khairy, \& Soilman, 2010)

\subsection{Sustainable Landscape in Arid Climate}

Aridity refers to a scarcity of moisture [15]; arid and semi-arid areas comprise approximately $35 \%$ of the global land surface [16,17]. Sustainable landscape design in these dry climates must consider natural resources including effective, efficient and appropriate water use [18,19]. Many mistakenly believe that stunning gardens and beautiful lawns are only possible through extensive watering, fertilization, and pesticide application. However, attractive landscapes that save water, prevent pollution, and protect the environment are easily achieved by employing water-efficient landscaping [20].

Several terms such as 'water-wise', 'waterconserving', 'water-smart', 'low-water', 'environmentally friendly', and 'native' landscape have been commonly used interchangeably to describe approaches to water-efficient landscaping. While varying in schools of thought and philosophy, these terms are all based on the same principles. One of the first conceptual approaches developed to formalize these principles is acknowledged as 'Xeriscape' landscaping [21]. 'Xeriscaping', is the term used to describe techniques of landscaping that conserve water and protects the environment. It's the

\footnotetext{
${ }^{2}$ Xeric is a biome characterized by, relating to, or requiring only a small amount of moisture. Xeriscape is a trademarked term, spelled with a capital $\mathrm{X}$, and pronounced zeer-escape. Denver Water welcomes the use of the term Xeriscape in books, articles, and speeches promoting water conserving landscape.
}

wise use of water through water-efficient landscaping: "Use water wisely, not wastefully" [22,23-170]. The word is a combination of the Greek word 'xeros' which means dry, and 'landscape'. It was first used in 1981 when the Denver, Colorado Water Department and the Associated Landscape Contractors of Colorado joined together to create a program enlisting public cooperation to make landscape water use more efficient [24]. They hold the trademark on the name Xeriscape.

Typically, Xeriscape design would include native plant species (figure 2). Native species are those that have been growing naturally within specific regional conditions; they are self-propagating, and require no additional water, nutrients, or maintenance. In addition, when the appropriate species are used in a planting project, they tend to be very 'well-behaved' which means that they have natural controls, so they will not become invasive as much non-native vegetation. Another wonderful benefit of native plant species is that since they have been growing in a region for hundreds or thousands of years, they accommodate animals, insects such as butterflies and other species that thriving on settings rich in native plant diversity

$[25,26,27]$. 


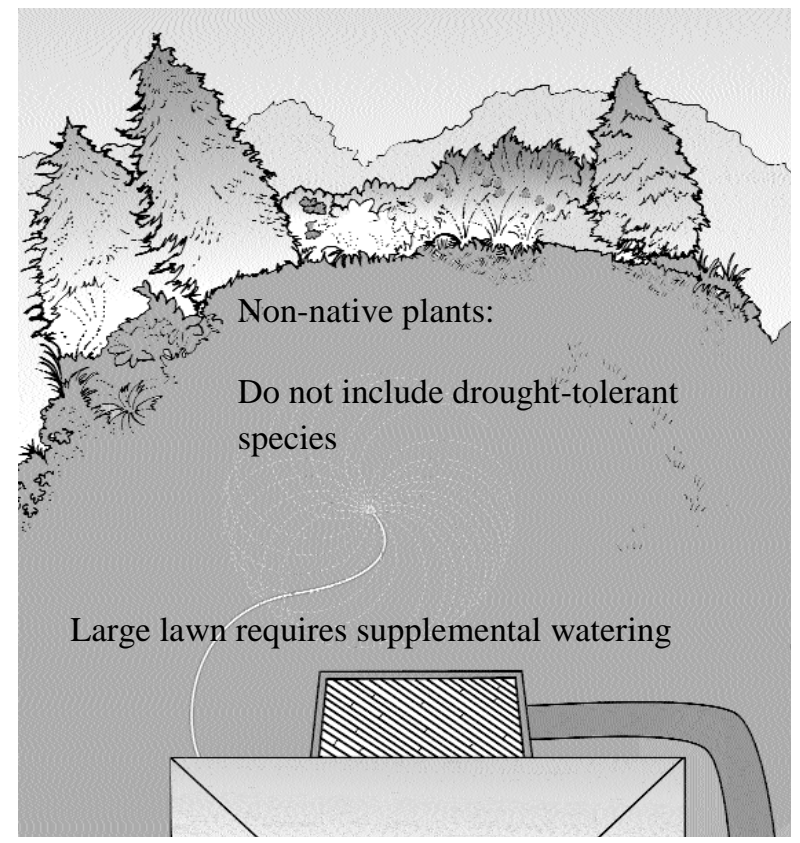

Non-Xeriscaping

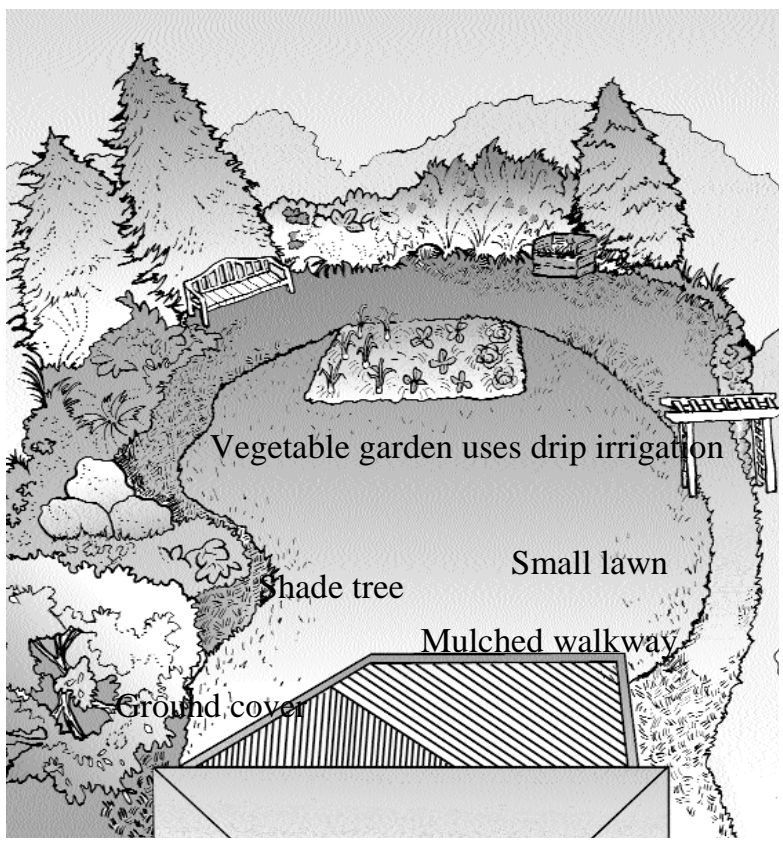

Xeriscaping

Fig 2. Non-Xeriscaping and Xeriscaping types. Source: Adapted from (Water-Efficient Landscaping: Preventing Pollution \& Using Resources Wisely, 2002) pp. 7\&8

\subsection{Benefits of water-efficient landscaping}

A. Economic benefits: Simply stated, water costs money to the community that supplies, treats, and recycle it. Economic benefits include also reduced landscaping labor and maintenance costs. Several studies investigated the economic benefits of water-efficient landscaping, for example: A study comparing 'conventional landscapes'3 and Xeriscapes (low-water-use landscaping) have shown that up to 50 percent savings can be achieved in water usage alone. Other studies indicate potential savings of nearly 30 percent in maintenance and labor, 61 percent in fertilizers, 44 percent in fuel and 22 percent in herbicides and pesticides [22]. As a last point is the research project conducted by the North Marin Water District in California to compare the use of outside water, landscape labor, fertilizer, fuel, and herbicides in traditional landscape projects with those in water conserving projects. The results showed an overall savings for the water conserving landscapes averaged $\$ 75$ per year per dwelling unit in a condominium or townhouse development. The reduction in water and labor costs accounted for more than 80 percent of the total savings. Most importantly, "a strong correlation was found between the perimeter of the turf and water use, indicating the turf perimeter may be the best

\section{parameter for defining a water conserving landscape" [28].}

B. Environmental benefits: Replacing the lawn dominant landscape with water-efficient landscaping can help reducing the use of fertilizers. In addition, by eliminating all or most of the plants that require excessive amounts of water and chemicals to sustain them, the local water supply is conserved and the remaining wastewater is less polluted and easier to clean and recycle. In addition, environmental benefits include conservation of natural resources and preservation of habitat for plants and wildlife plus decreased energy use and air pollution associated with its generation [20].

C. Aesthetic benefits: Proper landscaping techniques not only benefit the environment and save water, but also create beautiful landscapes. It is not "zero-scape" [29], on the contrary, water-efficient landscaping with the emphasis on the use of "native plants' or other suited to the local climatic condition offers the nation an opportunity to regain some of its regional distinctiveness, increase urban wildlife viewing and year-round visual interest, consequently, encourage link with nature and enhanced quality of life $[22,23]$.

\footnotetext{
3 The 'conventional' or 'traditional' landscape is characterized by large areas of turf accented by wellmanicured trees and shrubs.
} 
2.6. Do people prefer sustainable landscape? The answer for this question is certainly noteworthy because it can lead to landscape planning quandary. Sustainability includes both environmental protection and economic benefits "Who would not want environmental protection and economic benefits for as long as possible" [30-16].

Psychological research in human preferences has been based on 'rational model' that places considerable emphasis on logical, computational processes in choice and decision-makings. Applying the rational model to ecologically sustainable landscape, preferences should be strongly influenced by ecological knowledge. More precisely, "people with greater knowledge of ecosystems should be more likely to prefer ecologically sustainable landscape". Meanwhile, other research based on 'affective/evolutionary model' reveals that "environmental preferences may depend more on specialized affective reactions than on any knowledge-based logical operations" [30-17].

Neither the 'rational choice model' nor affective /evolutionary model' did answer the question of: 'Do people prefer sustainable landscape? However, if the answer to the question is that people do not prefer landscape, in that case potentially difficult political questions emerge: Should public aesthetic preferences be changed to favour sustainable landscapes? How should such a change be effected and by whom? Bearing in mind that "changing aesthetic preferences could require manipulating some or all of human perceptions, thoughts and feelings about the landscape" [30-24]. Additionally, (James L. Wescoat) [31] asserts that concern about the types of knowledge needed for sustainable landscape design dovetailed closely with discussions of the role of education in sustainable landscape design both in academic settings and in public settings.

\section{METHODOLOGY AND RESEARCH SCOPE}

\subsection{Resident Satisfaction Survey based on post-purchase value}

In marketing research, a distinction exists between pre-purchase and post-purchase value. The former refers to expectations regarding the value a product is going to deliver that are formed prior to purchase of the product. An individual's expectation can be a strong factor motivating that person's decision to that product. While Post-purchase value, on the other hand, involves value realized through the use of a product. Therefore, it can be argued that post-purchase value, or value-as-use, is more closely tied to the realities of the user's context. "The cues that motivate a customer's initial purchase of a product may differ from the criteria that connote value during use"[32]. In this context, a 'Resident Satisfaction Survey' was performed to learn more about residents of gated developments, their sustainability awareness and their satisfaction with their residential landscape.

\subsection{Measuring landscape sustainability} awareness

Landscape sustainability awareness was tested by means of two interrelated attributes; type of landscape and amount of turf. As previously mentioned, the turf perimeter is the best parameter for defining a water-efficient landscape. Specifically, 'limitation of turf to appropriate areas' reduces the use of water, fertilizers, and chemical.

\subsection{Measuring level of satisfaction}

Residents judge the value offered by their residential landscape: they assess their own benefit, sacrifice and resource criteria and the results are revealed in their degree of satisfaction.

\section{Benefits - Sacrifices}

$$
\begin{array}{ll}
\text { Value }=\simeq & \begin{array}{l}
\text { related to } \\
\text { Resources }
\end{array}
\end{array}
$$

The focus here will primarily be on user value, where value refers to the evaluation of some object (shared landscape) by some subject (user) [ibid]. The emphasis is on the use value related to the utility and the management of a residential landscape that is realized only upon its use.

A. Utility ${ }^{4}$ value refers to the fact that it might enable the accomplishment of a physical or emotional task. It encompasses convenience, quality, and emotion as sub-categories as follows:

- Convenience; including accessibility, and suitable area.

- Quality; concerned with the performance, the way in which shared landscape functions, driven by: presented activities, provided facilities, and existing landscaping.

- Emotion; referring to the affective benefits from aesthetic appeal provoking strong feelings such as pleasure and fun.

B. Management Value focuses on the subsidiary effects of decisions on long term operating costs and performance of shared landscape. It encompasses maintenance and the value of integrating users' judgement into managing process.

\section{METHODS}

A self-administered questionnaire was developed for conducting the Resident Satisfaction Survey: It was designed to assess residents'

\footnotetext{
${ }^{4}$ In economics, utility is a measure of relative satisfaction it is a term referring to the total satisfaction received by a consumer from consuming a good or service.
} 
satisfaction with their residential landscape along with their sustainability awareness. The questionnaire was constructed based on the review of literature in addition to questions adapted from 'Neighbourhood Question Bank' . Questionnaire design and forms mostly followed Total Design Method (TDM) guidelines for questionnaire preparation [33]. The survey was assessed for reliability using a test-retest method to verify that responses were consistent over time (two weeks).

Both descriptive and inferential statistics were been used to analyse the same set of data by utilization of SPSS Statistics (17.0). Specific methods from three models are taken as appropriate methods to use in this study:

- From the exploratory model; frequency distributions for the general characteristics of respondents; weighted average for satisfaction rating; and measures of dispersion (i.e. range, quartiles, standard deviation, sample variance) to summarize how spread out the scores are.

- From the experimental model; the chisquare test for assessing environmental awareness; the simple t-test and one-way ANOVA are used to identify consensus and difference in responses.

- From the predictive model, regression analysis is selected for predicting on degree of satisfaction.

\section{RESULTS}

\subsection{Respondents characteristics}

In general, the study dealt with residents of 16 GRDs from various areas. The total number of responses to the resident survey was 76. Among them, $36.8 \%$ were male and $63.2 \%$ were female. The age of the respondents was categorized into three groups; $18.4 \%$ were less than 21 years old, $57.9 \%$ were in the age group of 21 to 35 years old, and $23.7 \%$ were in the age group of 36 to 60 years old. Among the 76 respondents, $33.3 \%$ were single and $66.7 \%$ were married. The family size of the respondents was also categorized into three groups; $16.2 \%$ were in $1-2$ group, $59.5 \%$ were in $3-4$ group, and $24.3 \%$ were more than four family members. 43 dwelling units out of 76 were individual houses with a percentage of $56.6 \%$, and 33 were apartment flats with a percentage of $43.4 \%$. Since such gated projects are a new (mostly post-2000) phenomenon, $22.7 \%$ respondents had lived there less than one year; $44 \%$; respondents had lived there from one to three

\footnotetext{
${ }^{5}$ The ESRC Centre for Neighbourhood Research (CNR), available at

http://www.neighbourhoodcentre.org.uk/bank/bank.html
}

years; and $33.3 \%$ respondents had lived there longer than three years.

\subsection{Respondents' sustainability awareness}

People with greater environmental knowledge should be more likely to prefer waterefficient landscaping (WEL) and consequently approve the limitation of turf ${ }^{6}$ to appropriate areas. However the results show that slightly more than two fifths $42.7 \%$ of respondents preferred water efficient landscaping (WEL), while more than half of them $57.3 \%$ approved that 'landscape type doesn't make a difference' for them. Lawns preferences were $49.3 \%$ for lot of lawn, and $50.7 \%$ for practical turf areas. This is leading to the following main question:

\section{Do preference for 'Practical turf areas' is influenced by environmental knowledge or depend more on specialized affective reaction than on any knowledge-based logical operation?}

The answer for this question is certainly noteworthy, therefore, a second step of the data analysis inferential statistics- was performed. Chi-Square Test for Independence was used to determine whether there is a significant association relationship between the two categorical variables (A and B) as follows;

\begin{tabular}{|l|}
\hline Variable A (independent variable) \\
Type of landscape: \\
1. Water-efficient landscaping (WEL). \\
2. Type doesn't make a difference. \\
Variable B (dependent variable) \\
Amount of turf: \\
1. Lot of lawn \\
2. Practical turf areas (play area for children \\
\& sports).
\end{tabular}

The test statistic equation (1): chi-square random variable $\left(\mathrm{X}^{2}\right)$ is defined as follows:

$\mathrm{X}^{2}=\Sigma\left[\left(\mathrm{O}_{\mathrm{r}, \mathrm{c}}-\mathrm{E}_{\mathrm{r}, \mathrm{c}}\right)^{2} / \mathrm{E}_{\mathrm{r}, \mathrm{c}}\right]$ (1)

Where:

$\mathbf{O}_{\mathbf{r}, \mathbf{c}}$ is the observed frequency count at level $\mathrm{r}$ of Variable A and level c of Variable B, and $\mathbf{E}_{\mathbf{r}, \mathbf{c}}$ is the expected frequency count at level $\mathrm{r}$ of Variable A and level c of Variable B.

$\left(\mathrm{H}_{\mathrm{o}}\right)$ : Variable A and Variable B are independent. $\left(\mathrm{H}_{\mathrm{a}}\right)$ : Variable A and Variable B are not independent. The result indicates that the relation between variables $(\mathrm{A}$ and $\mathrm{B})$ was not significant, $\mathrm{X}^{2}(1, \mathrm{~N}=$ $74)=0.22 \mathrm{p}>.05^{7}$. Since the P-value (0.639) is greater than the significance level (0.05), the null

\footnotetext{
${ }^{6}$ Turf: a surface layer of earth containing a dense growth of grass and its matted roots; sod. Source: http://www.answers.com/topic/turf\#ixzz1ajqFXIbY 7 The approach is appropriate because: no cell has an expected frequency less than 1 , and no more than $20 \%$ of cells have an expected frequency less than 5 .
} 
hypothesis is accepted and the two variables are independent.

Thus, it can be concluded that there is no relationship between 'Type of landscape' and 'Amount of turf'. In this perspective, preference for 'Practical turf areas' is not influenced by environmental knowledge; it appears do depend more on specialized affective reaction than on any knowledge-based logical operation (figure 3).

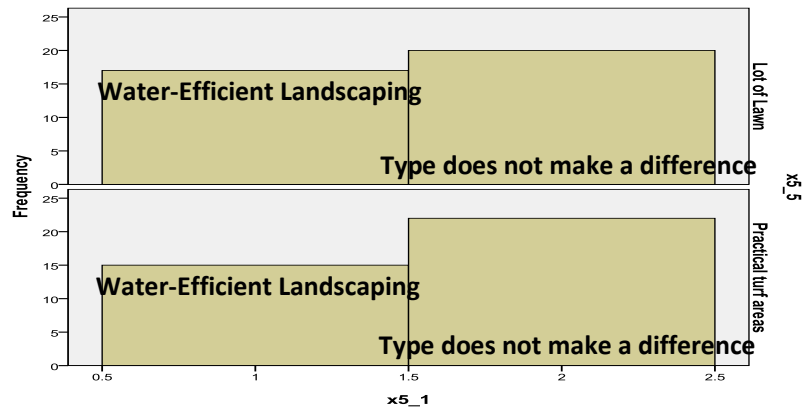

Fig 3. Number of respondents who assisted at each group .

For a more elaborate analysis of the differences in responses, the effects of demographic and housing characteristics on residential landscape type preferences were tested based on the data collected from the questionnaire using Independent T-Test or One-way ANOVA depending on variables levels.

For both the demographic factor (i.e. gender; age; marital status; number of family members) and familiarity factor (i.e. Duration of residence), they have no effect on landscape type preference. Only socio-economic factor (i.e. type of residence has influenced landscape type preference as follows:

Villas dwellers $(\mathrm{M}=1.49, \mathrm{SD}=.506)$ reported significantly less preference for water efficient type of landscape than for flat dwellers $(\mathrm{M}=1.68$, $\mathrm{SD}=.475), \mathrm{t}(72)=-1.627, \mathrm{p}=0.017)$.

\subsection{Respondents' degree of satisfaction}

This study is aimed at firstly, measuring residents' satisfaction with their residential landscape then, to find out if residents' degree of satisfaction can be predicted based on integration of their value judgements into management process. Nine variables were dealing with specific aspects of the environment being discussed: size, location, activities, facilities, landscaping, aesthetic appeal, the quality of the greenery/maintenance (at the beginning of the project and now), and level of integration of users value judgements in managing process. Attributes are assessed through a 5-point rating scale accompanied by a visual analog scale (VAS) where " 5 " refers to the most positive evaluation and " 1 " refers to the most negative evaluation.

The simple analysis of trends shows that in general satisfaction levels are high: the respondents are more likely to be satisfied even when background characteristics were held constant ${ }^{8}$. For the majority of variables, $25 \%$ of scores were equal or less than four (good). And 25\% of scores for 'Opportunities for use \& activities'(v3) and 'Landscape \& Plants looked beautiful at the beginning of the project' (v7) were equal or less than three (average) (figure 4).

The grouping Table 1 below shows respondents' level of satisfaction:

- Considering utility of residential landscape, respondents were far more satisfied with the emotional variable 'Aesthetic appeal' (weight average of $v 6=89 \%$ ): more than two-thirds of all the residents $(67.1 \%)$ give v6 a satisfaction score of 5 out of 5 , and only a handful $(13.2 \%)$ give it a satisfaction score of 1 out of 5 .

- As for management of landscape, most residents rated the two aspects of maintenance as good to very good. It can be inferred from the difference between the two values (weight average of $\mathrm{v} 7=75 \%$; weight average of $\mathrm{v} 8=89.5 \%$ ) that the quality of the greenery has enhanced over time. Residents were also pleased with the integration of their judgments into the management process (weight average of $\mathrm{v} 9=80.2 \%$ ).

Taking these observations as a starting point, it would be tempting to conclude that developers were responsible for these positive results with regard to satisfaction. The level of satisfaction that a respondent expresses on a survey is related to how well the space meets expectations. Individuals, who in the past received low levels of service, will as a result have low expectations and in turn will be satisfied with an acceptable level of service. Nevertheless, new experiences lead to new levels of expectation that may alter the levels of satisfaction [34].

\footnotetext{
8 - Previous research has identified sets of personal factors (e.g. age, length of residence) as having an impact on residents' satisfaction.
} 
Box plot ${ }^{9}$

\begin{tabular}{|c|c|c|}
\hline & & Percentiles \\
\hline & V group & $25^{a} 50^{b} 75^{c}$ \\
\hline Tukey's Hinges & v1 & 4.005 .005 .00 \\
\hline & v2 & 4.005 .005 .00 \\
\hline & v3 & 3.005 .005 .00 \\
\hline & v4 & 4.005 .005 .00 \\
\hline & v5 & 4.005 .005 .00 \\
\hline & v6 & 4.005 .005 .00 \\
\hline & v7 & 3.004 .005 .00 \\
\hline & v8 & 4.005 .005 .00 \\
\hline & v9 & 4.004 .005 .00 \\
\hline
\end{tabular}

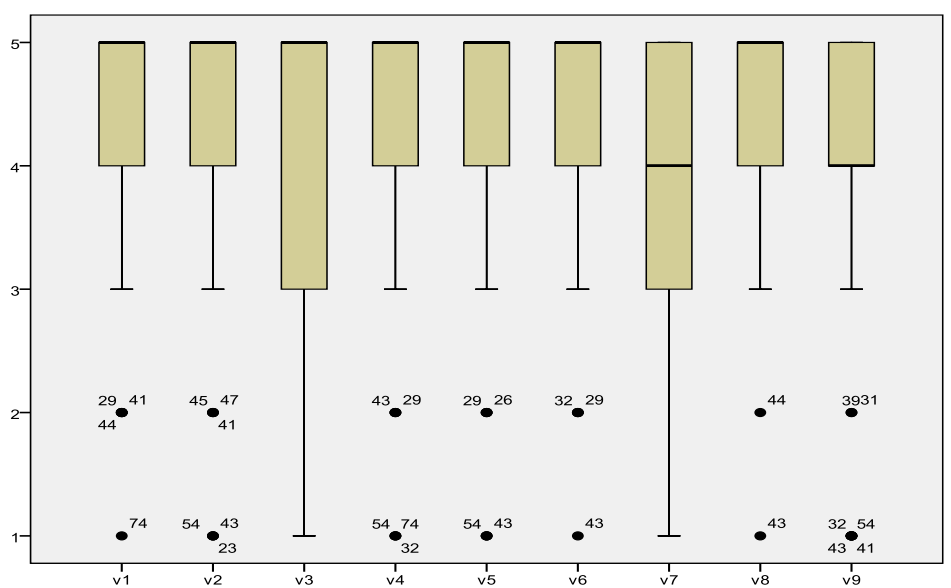

NOTE: All v group (except v7) have a data set in which the median and the third quartile are the same. In this case, the diagram would not have a dotted line inside the box displaying the median. The top of the box displays both the third quartile and the median.

a. 25 th percentile (Q1): $25 \%$ of data less than this value

b. 50 th percentile or the median (Q2): $50 \%$ of data greater than this value (middle of dataset)

c. 75 th percentile (Q3): $25 \%$ of data greater than this value

Fig 4 Trends in shared open spaces evaluation (V group)

Table 1. Questionnaire responses to degree of satisfaction variables (V group)

\begin{tabular}{|c|c|c|c|c|c|c|c|c|c|c|}
\hline \multirow{2}{*}{\multicolumn{3}{|c|}{$\begin{array}{lr} & \text { Variables } \\
\text { Description }\end{array}$}} & \multirow{2}{*}{ Mean } & \multicolumn{5}{|c|}{ Percent \%* } & \multicolumn{2}{|c|}{ Weighted Average } \\
\hline & & & & 1 & 2 & 3 & 4 & 5 & Percent & Description \\
\hline \multirow{8}{*}{$\stackrel{3}{:}$} & v1 & Suitable area & 4.38 & 1.3 & 5.3 & 10.5 & 18.4 & 61.8 & 87.6 & very good \\
\hline & v2 & Accessibility & 4.28 & 3.9 & 3.9 & 7.9 & 26.3 & 55.3 & 85.7 & very good \\
\hline & v3 & Opportunities for use \& & & & & & & & & \\
\hline & v3 & Activities & 4.12 & 2.6 & 7.9 & 17.1 & 17.1 & 52.6 & 82.4 & very good \\
\hline & $\mathrm{v} 4$ & Facilities provided & 4.24 & 3.9 & 3.9 & 13.2 & 19.7 & 56.6 & 84.9 & very good \\
\hline & v5 & Landscaping (Design/ Planting & & & & & & & & \\
\hline & v5 & Design) & 4.30 & 3.9 & 3.9 & 7.9 & 23.7 & 56.6 & 86 & very good \\
\hline & v6 & Aesthetic Appeal & 4.46 & 2.6 & 3.9 & 6.6 & 17.1 & 67.1 & 89 & very good \\
\hline \multirow{3}{*}{ 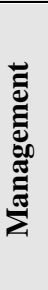 } & v7 & $\begin{array}{l}\text { Landscape \& Plants looked } \\
\text { beautiful at the beginning of } \\
\text { the project }\end{array}$ & 3.73 & 5.3 & 10.5 & 25 & 21.1 & 35.5 & 75 & good \\
\hline & v8 & $\begin{array}{l}\text { Landscape \& Plants look } \\
\text { beautiful now }\end{array}$ & 4.47 & 1.3 & 2.6 & 9.2 & 19.7 & 64.5 & 89.5 & very good \\
\hline & v9 & $\begin{array}{l}\text { Users value judgments are } \\
\text { taken into account by the } \\
\text { project manager }\end{array}$ & 4.01 & 6.6 & 2.6 & 11.8 & 38.2 & 38.2 & 80.2 & very good \\
\hline
\end{tabular}

\footnotetext{
${ }^{9}$ The Tukey box plot shows the first (bottom of box) and third (top of box) quartiles (equivalently the 25th and 75 th percentiles), the median (the horizontal line in the box), the range (excluding outliers and extreme scores) (the "whiskers" or lines that extend from the box show the range), outliers (a circle represents each outlier -- the number next to the outlier is the observation number.) An outlier is defined as a score that is between 1.5 and 3 box lengths away from the upper or lower edge of the box (remember the box represents the middle 50 percent of the scores). An extreme score is defined as a score that is greater than 3 box lengths away from the upper or lower edge of the box.
} 
It is important to note that the current study is not merely designed to study the evaluation of residential landscape in GRDs, but to decipher a factor that prevails as affecting the degree of resident's satisfaction. Therefore, a second step of the data analysis -inferential statistics - will go beyond a simple description of trends in levels of satisfaction. Simple linear regression analyses were used for testing if 'Integrating Users Value Judgements' significantly predicted residents' ratings of values of the parameter that determines the degree of satisfaction.

The standard form for the linear regression equation (2) is defined as follows:

$\mathrm{Y}$

(2)

$=\mathrm{a}+\mathrm{bX}+\mathrm{u}$

Where:

$\mathbf{Y}$ is the estimated score for the dependent variable (variable that we are trying to predict).

$\mathbf{X}$ is the score for the independent variable (variable that we are using to predict $\mathrm{Y}$ ).

b is the slope of the regression line, or the multiplier of $\mathrm{X}$.

$\mathbf{a}$ is the intercept (the point on the vertical axis where the regression line crosses the vertical $y$ axis).

$\mathbf{u}$ is the regression residual.

The purpose of simple linear regression analysis is to answer three questions that have been identified as requirements for understanding the relationship between the independent variable (v9) and each of the dependent variables (v1, v2, v3, v4, v5, v6, v7, v8):

- Is there a relationship between the independent variable and dependent variables?

- What is the direction of the relationship (high scores are predictive of high or low scores)?

- How strong is the relationship (e.g. trivial, weak, moderate or strong; how much does it reduce error)?

According to the test results in Table 2 and Linear Regression Curve Estimation in figure 5, there has been a statistically significant predicting effect of 'Integrating Users Value Judgements' on all value variables, meaning that high scores for (v9) are a useful predictor of (v1, v2, v3, v4, v5, v6, v7, v8) high scores as follows:

\section{Convenience}

Suitable area: Simple linear regression revealed a statistically positive significant relationship between 'Integrating Users Value Judgements' and 'Suitable area'. Higher scores for the independent variable ( $v 9)$ are associated with scores on the dependent variable (v1) $(\beta=0.650, t(72)=7.250, p<.001)$. Using Cohen's criteria for characterizing the strength of relationships, the correlation coefficient $(r=0.650)$ was correctly interpreted as a large relationship ${ }^{10}$. The linear regression model is proposed below;

Level of Satisfaction with 'Suitable area' $=$ $2.101+(0.567)$ 'Users value judgments are taken into account by the project manager'

Accessibility: Simple linear regression revealed a statistically positive significant relationship between 'Integrating Users Value Judgements' and 'Accessibility'. Higher scores for the independent variable $(v 9)$ are associated with scores on the dependent variable $(v 2)(\beta=0.474, t(72)=4.570, p$ $<.001)$. Using Cohen's criteria for characterizing the strength of relationships, the correlation coefficient ( $\mathrm{r}$ $=0.474$ ) was correctly interpreted as a moderate relationship. The linear regression model is proposed below;

Level of Satisfaction with 'Accessibility' = $2.488+(0.447)$ 'Users value judgments are taken into account by the project manager'

\section{Quality \& Performance}

Opportunities for use \& Activities: Simple linear regression revealed a statistically positive significant relationship between 'Integrating Users Value Judgements' and 'Opportunities for use \& Activities'. Higher scores for the independent variable $(v 9)$ are associated with scores on the dependent variable $(v 3)(\beta=0.669, t(72)=7.646, p$ $<.001)$. Using Cohen's criteria for characterizing the strength of relationships, the correlation coefficient ( $\mathrm{r}$ $=0.669$ ) was correctly interpreted as a large relationship. The linear regression model is proposed below;

Level of Satisfaction with 'Opportunities of use \& Activities' =

$1.392+(0.680)$ 'Users value judgments are taken into account by the project manager'

Facilities provided: Simple linear regression revealed a statistically positive significant relationship between 'Integrating Users Value Judgements' and 'Facilities provided'. Higher scores for the independent variable $(v 9)$ are associated with scores on the dependent variable $(v 4)(\beta=0.692$, $t(72)=8.126, p<.001)$. Using Cohen's criteria for characterizing the strength of relationships, the correlation coefficient $(r=0.692)$ was correctly interpreted as a large relationship.

The linear regression model is proposed below;

\footnotetext{
${ }^{10}$ Cohen's criteria:

- $\quad \mathrm{r}<.1=$ Trivial

- $.1 \leq \mathrm{r}<.3=$ Small

- $.3 \leq \mathrm{r}<.5=$ Medium or moderate

- $\mathrm{r} \geq .5=$ Large
} 
Level of Satisfaction with 'Facilities provided' = $1.519+(0.679)$ 'Users value judgments are taken into account by the project manager'

Landscaping: Simple linear regression revealed a statistically positive significant relationship between 'Integrating Users Value Judgements' and 'Landscaping'. Higher scores for the independent variable (v9) are associated with scores on the dependent variable $(v 5)(\beta=0.659, t(71)=7.387, p$ $<.001)$. Using Cohen's criteria for characterizing the strength of relationships, the correlation coefficient ( $\mathrm{r}$ $=0.659$ ) was correctly interpreted as a large relationship. The linear regression model is proposed below;

Level of Satisfaction with 'Landscaping' = 1. $776+(0.627)$ 'Users value judgments are taken into account by the project manager'

\section{Emotional}

Aesthetic Appeal: Simple linear regression revealed a statistically positive significant relationship between 'Integrating Users Value Judgements' and 'Aesthetic Appeal'. Higher scores for the independent variable $(v 9)$ are associated with scores on the dependent variable $(v 6)(\beta=0.569, t(72)=$ 5.873, $p<.001)$. Using Cohen's criteria for characterizing the strength of relationships, the correlation coefficient $(r=0.569)$ was correctly interpreted as a large relationship. The linear regression model is proposed below;

Level of Satisfaction with 'Aesthetic Appeal' = $2.45+(0.501)$ 'Users value judgments are taken into account by the project manager'

\section{Maintenance}

Landscape \& Plants at the beginning of the project: Simple linear regression revealed a statistically positive significant relationship between 'Integrating Users Value Judgements' and 'Landscape \& Plants looked beautiful at the beginning of the project'. Higher scores for the independent variable $(v 9)$ are associated with scores on the dependent variable $(v 7)(\beta=0.445, t(72)=$ 4.221, $p<.001)$. Using Cohen's criteria for characterizing the strength of relationships, the correlation coefficient $(\mathrm{r}=0.445)$ was correctly interpreted as a moderate relationship. The linear regression model is proposed below;

Level of Satisfaction with 'Landscape \& Plants looked beautiful at the beginning of the project' = $1.777+(0.487)$ 'Users value judgments are taken into account by the project manager'

Landscape \& Plants now: Simple linear regression revealed a statistically positive significant relationship between 'Integrating Users Value Judgements' and 'Landscape \& Plants look beautiful now'. Higher scores for the independent variable $(v 9)$ are associated with scores on the dependent variable (v8) $(\beta=0.621, t(72)=6.728, p<.001)$. Using Cohen's criteria for characterizing the strength of relationships, the correlation coefficient $(r=0.621)$ was correctly interpreted as large relationship. The linear regression model is proposed below;

Level of Satisfaction with 'Landscape \& Plants
looked beautiful now' =
$2.509+(0.489)$ 'Users value judgments are taken
into account by the project manager'


Faisal Abdul Maksoud, Seamus Filor and Ghada Yassein, "Shared Open Spaces In Gated ..."

Table 2. Simple linear regression models for examining the predicting effect of integration 'Users' Value Judgements'

\begin{tabular}{|c|c|c|c|c|c|}
\hline \multirow{2}{*}{$\begin{array}{c}\text { Independent } \\
\text { variable }\end{array}$} & \multicolumn{2}{|c|}{ Types of value } & \multirow[b]{2}{*}{ Dependent variables } & \multirow{2}{*}{$\begin{array}{c}\text { Simple Linear } \\
\text { Regression Model }\end{array}$} & \multirow{2}{*}{$\begin{array}{c}\text { Coefficient of } \\
\text { determinatio } \\
\mathbf{n} \\
\text { (R-Square) }\end{array}$} \\
\hline & Major category & Subcategory & & & \\
\hline \multirow{8}{*}{$\begin{array}{l}\quad(\nu 9) \\
\text { Integrating } \\
\text { Users' Value } \\
\text { Judgements }\end{array}$} & \multirow{6}{*}{ UTILITY } & \multirow[t]{2}{*}{ Convenience } & (v1) Suitable area* & $\mathrm{v} 1=2.101+(0.567) \mathrm{v} 9$ & $R^{2}=.422$ \\
\hline & & & (v2) Accessibility* & $\mathrm{v} 2=2.488+(0.447) \mathrm{v} 9$ & $R^{2}=.225$ \\
\hline & & \multirow[t]{3}{*}{$\begin{array}{l}\text { Quality \& } \\
\text { Performance }\end{array}$} & $\begin{array}{l}\text { (v3) Opportunities for use } \\
\& \text { Activities* }\end{array}$ & $\mathrm{v} 3=1.392+(0.680) \mathrm{v} 9$ & $R^{2}=.448$ \\
\hline & & & (v4) Facilities provided & $\mathrm{v} 4=1.519+(0.679) \mathrm{v} 9$ & $R^{2}=.478$ \\
\hline & & & $\begin{array}{l}\text { (v5) Landscaping* } \\
\text { (Design/ Planting Design) }\end{array}$ & $\mathrm{v} 5=1.776+(0.627) \mathrm{v} 9$ & $R^{2}=.435$ \\
\hline & & Emotional & (v6) Aesthetic Appeal* & $\mathrm{v} 6=2.45+(0.501) \mathrm{v} 9$ & $R^{2}=.324$ \\
\hline & \multirow[t]{2}{*}{$\begin{array}{c}\text { MANAGEMEN } \\
\mathrm{T}\end{array}$} & \multirow[t]{2}{*}{ Maintenance } & $\begin{array}{l}\text { (v7) Landscape \& Plants } \\
\text { looked beautiful at the } \\
\text { beginning of the project* }\end{array}$ & $\mathrm{v} 7=1.777+(0.487) \mathrm{v} 9$ & $R^{2}=.198$ \\
\hline & & & $\begin{array}{l}(v 8) \text { Landscape \& Plants } \\
\text { look beautiful now* }\end{array}$ & $\mathrm{v} 8=2.509+(0.489) \mathrm{v} 9$ & $R^{2}=.386$ \\
\hline
\end{tabular}

* This regression model is significant at the .001 level.

Suitable Area (v1):

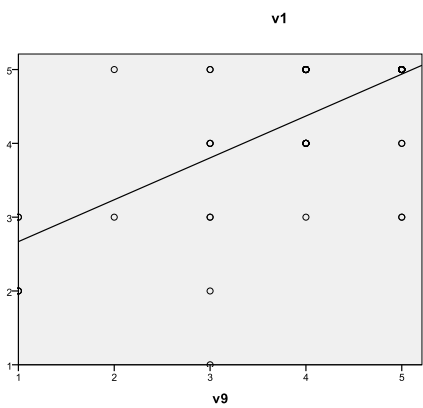

Opportunities of use \& Activities (v3):

v3

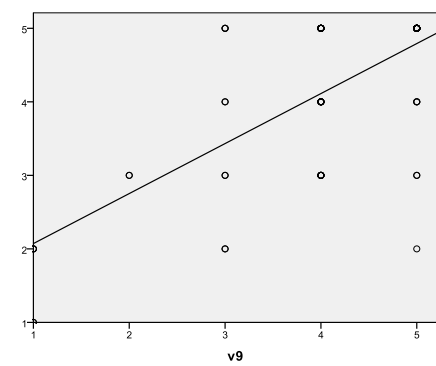

Design/Planting design (v5):

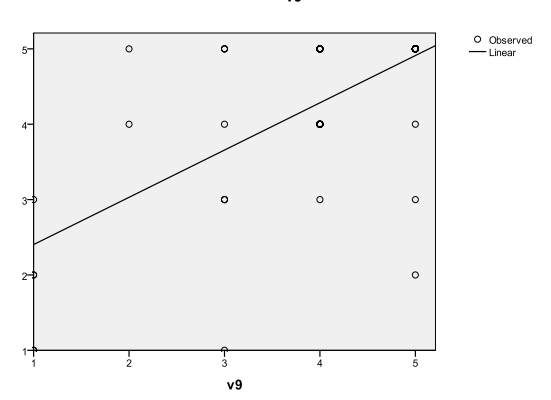

Accessibility (v2):

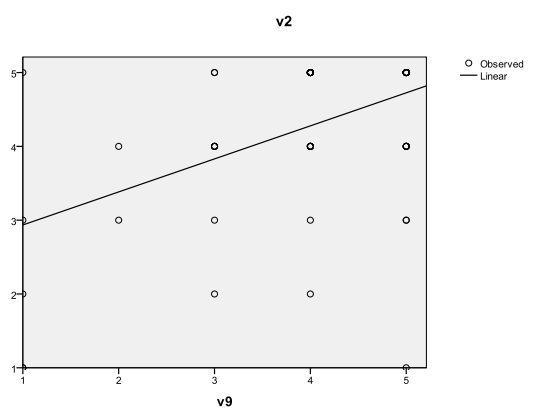

Facilities (v4):

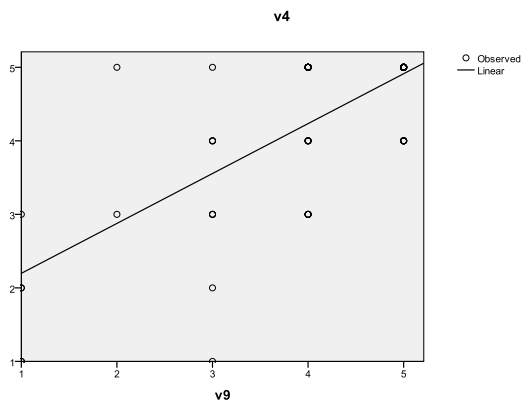

Aesthetic appeal (v6):

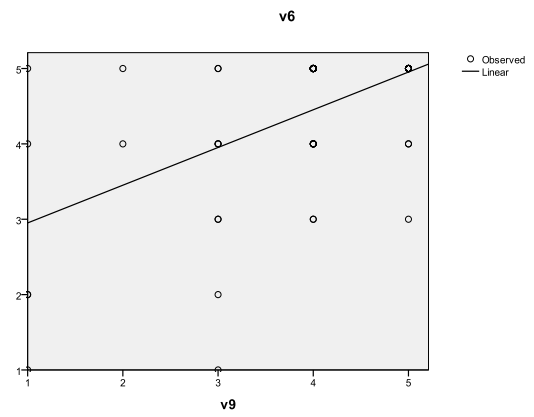


Plants looked beautiful at the beginning (v7):

v7

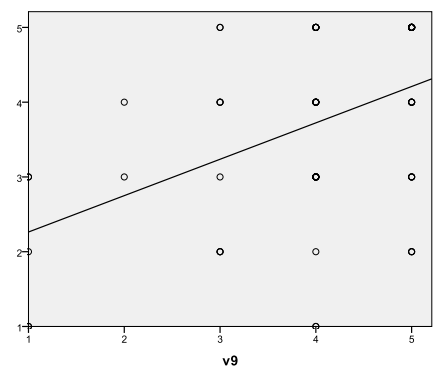

Plants look beautiful now (v8):

v8

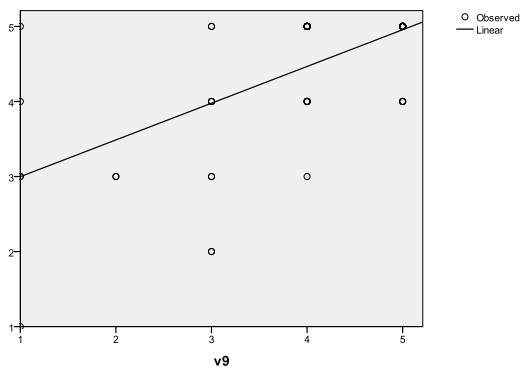

Fig 5. Linear Regression Curve Estimation

\section{DISCUSSION AND CONCLUDING REMARKS:}

There was no significant effect of demographic factor (gender- age- marital status - number of family members) or familiarity factor (duration of residence) on residential landscape type preferences. Also, 43\% of respondents express some environmental concern, they could make conscious choices about the world they live in but need the extra push to reflect that concern in their preferences. It could be said that, certain individuals will always be motivated to make environmentally responsible choices and others will probably always be indifferent, at least for now.

Stronger environmental attitudes lead to compromises on the amount of turf preferred. However, it can be concluded that in spite of the low environmental awareness, half on respondents approved the limitation of turf to appropriate areas. Thereby, preference for 'Practical turf areas' tend to be more influenced by affective reaction than by environmental knowledge or demographic factor.

The participation of residents in management process was found to be particularly important for a higher level of satisfaction with residential landscape; this find is of interest for the following reasons:

- For one thing, residents' participation in the management process ensures their enduring satisfaction hence protecting the development from potential decay or a loss of property values.

- For another, residents' participation in the management process should facilitate the implementation of sustainability measures with regard to the quality and performance of the residential landscape.

In conclusion, to achieve greater success concerning sustainability of residential landscape as well as residents' satisfaction, sustainability concepts need to be understood and acknowledged by all those involved, from the upper management and design team to the residents. In that sense, landscape professions should present understandable facts and objectives about sustainable landscapes to the public through government and organizations. At the same time, marketers can play the role of environmental educators; they can use advertising campaigns to increase consumer concern about water efficiency issues to enhance their future customer environmental awareness. Also, developers must be clear about the development's sustainable attributes, advertise the convenience of water efficient landscaping, and explain its long-lasting effects. Additionally, on site education is quite important to increase levels of sustainable practices and to engage residents in decisions about the quality and sustainability of their landscape. 


\section{ACKNOWLEDGEMENTS:}

This paper arises from a research conducted as part of the requirements for the degree of Doctor of Philosophy.

Special thanks are given to Hala Kamel for her strong support while distributing and collecting the questionnaire. And thanks to the anonymous reviewer.

\section{REFERENCES:}

[1] Faiks, S., Kest, J., Szot, A., \& Vendura, M. (2001). Revisiting Riverside: A Frederick Law Olmsted Community. Retrieved December, 2010, from

http://www.snre.umich.edu/ecomgt/pubs/riverside /RSchapter1.pdf

[2] Bell, S. (1999). Landscape: pattern, perception, and process. London: E \& F N Spon.

[3] Amerigo, M., \& Aragon'es, J. I. (1997). Residential satisfaction in council housing. Journal of Environmental Psychology(10), 313325.

[4] Kim, J., \& Kaplan, R. (2004). Physical and Psychological Factors in Sense of Community. Environment and Behavior, 36(3), 313-340.

[5] Kaplan, R. (1983). The role of nature in the urban context. In I. Altman \& J. F. Wohlwill (Eds.), Behavior and the natural environment (pp. 127159). New York: Plenum Press.

[6] Kaplan, R. (2001). The nature of the view from home. Environment and Behavior, 33(4), 507542.

[7] Lee, S.-W., 2002. The relationship between landscape structure and neighborhood satisfaction. Ph.D. Dissertation. Texas A\&M University, TX.

[8] Kaplan, R., Kaplan, S., \& Ryan, R. (1998). With people in mind: Design and management of everyday nature. Washington, DC: Island.

[9] Pease, M. (1995). Sustainable Communities: What's Going On Here? Places, 9(3), 50.

[10] Lyndon, D. (1995). A Shift in Expectations. Places, 9(3), 2.

[11] Lyndon, D. (1995). A Shift in Expectations. Places, 9(3), 2.

[12] World Commission on Environment and Development. (1987). Our Common Future. New York: Oxford University Press.

[13] Association of Professional Landscape Designers (APLD).Sustainability Guidelines for Landscape Design, from http://www.docstoc.com/docs/22956391/APLDSustainability-Guidelines-for-Landscape-Design
[14] Selman, P. (2008). What do we mean by "sustainable landscape"? Sustainability: Science, Practice, \& Policy, 4(2), 23-28.

[15] James L. Wescoat, J. ( 1996a, December, 7). A Geographical Perspective on Sustainable Landscape Design in Arid Environments. Paper presented at the Sustainable Landscape Design in Arid Climates, Dumbarton Oaks.

[16]Burmil, S., Daniel, T. C., \& Hetherington, J. D. (1999). Human values and perceptions of water in arid landscapes. Landscape and Urban Planning, 44, 99-109.

[17] Heathcote, R. L. (1985). The Arid Lands: Their Use and Abuse. London: Longman.

[18] Bödeker, R. ( 1996, December, 7). Gardens in the Desert: A Landscape Architect in Saudi Arabia. Paper presented at the Sustainable Landscape Design in Arid Climates, Dumbarton Oaks.

[19] Botanic Gardens of Adelaide. Sustainable Landscapes brochure: What is a Sustainable Landscape? Retrieved May, 10, 2010, from http://www.environment.sa.gov.au/botanicgarden s/pdfs/sustainable.pdf

[20] Landscaping for Water Efficiency. Retrieved January, 2, 2011, from http://www.cedengineering.com/upload/WaterEfficient\%20Landscaping.pdf

[21] Water Efficiency: Water Management Options. (2009). Raleigh,: North Carolina Division of Pollution Prevention and Environmental Assistance.

[22] Majerus, M., Reynolds, C., Scianna, J., Winslow, S., Holzworth, L., \& Woodson, E. (2001). Creating Native Landscapes in the Northern Great Plains and Rocky Mountains. Washington, DC: Unite States Department of Agriculture (USDA).

[23] Ingels, J. E. (2004). Landscaping: principles and practices (6th ed.). New York, NY: Delmar Publishing Inc.

[24] Knox, G. W. (2003). Landscape Design for Water Conservation (No. ENH72). Florida: Environmental Horticulture Department, Florida Cooperative Extension Service, Institute of Food and Agricultural Sciences (IFAS), University of Florida.

[25] LANLSustainable Design Guide: Landscape Design and Management. (2002). from http://apps1.eere.energy.gov/buildings/publicatio $\mathrm{ns} /$ dffs/commercial_initiative/sustainable_guide_ ch7.pdf

[26] Low Maintenance Landscaping. (1992). Kansas State University Agricultural Experiment Station and Cooperative Extension Service. 
[27] Salsedo, C. A., \& Crawford, H. M. (2000). Going Native - Rethinking Plant Selection for the Home Landscape: Clean Water Fact Sheet, produced by NEMO and Sea Grant Connecticut.

[28] Nelson, J. O. (1987). Water Conserving Landscapes Show Impressive Savings. Journal of the American Water Works Association (AWWA), 79(3), pp. 35-42.

[29] Leggett, A. A. (2009). Insiders' Guide to Boulder and Rocky Mountain National Park: Globe Pequot Press.

[30] Daniel, T. C. (2001). Aesthetic Preferences and Ecological Sustainability. In S. R. J. Sheppard \& H. W. Harshaw (Eds.), Forests and landscapes: linking ecology, sustainability, and aesthetics (pp. 15-30). New York: CABI.

[31] James L. Wescoat, J. ( 1996b, December, 7). Summary of Discussion and Future Concerns. Paper presented at the Sustainable Landscape Design in Arid Climates, Dumbarton Oaks.

[32] Boztepe, S. (2007). User Value: Competing Theories and Models. International Journal of Design, 1(2), 55-63.

[33] Touliatos, J., \& Compton, N. H. (1983). Research Methods in Human Ecology/ Home Economics. Ames, IA: Iowa State University Press.

[34] Varady, D. P., \& Carrozza, M. A. (2000). Toward a Better Way to Measure Customer Satisfaction Levels in Public Housing: A Report from Cincinnati. Housing Studies, 15(6), 797825. 